\title{
Phytochemical, antimicrobial, antioxidant and enzyme inhibitory potential of medicinal plant Dryopteris ramosa (Hope) C. Chr.
}

\author{
Fiaz Alam ${ }^{1 *}$, Syed Hurmat Ali Khan ${ }^{1}$ and Mohammad Hassham Hassan Bin Asad ${ }^{1,2}$
}

\begin{abstract}
Background: Dryopteris ramosa has numerous potentials uses in the treatment of different maladies as old traditional medication. The fronds of $D$. ramose are edible and orally administered for producing antibiotic effect. They are also used as astringent and febrifuge, and as a pesticide.

Methods: Extraction of fronds of D. ramosa using solvents of increasing polarity, namely, ethyl acetate, methanol and water were tested for phytochemical (qualitative tests, GC-MS), antimicrobial (well method), antioxidant (DPPH), antifungal (tube dilution), cytotoxic activity (brine shrimps lethality assay) and LOX and COX inhibitory activities were performed using standard methods.

Results: The phytochemical analysis of the crude methanolic extract revealed that the fronds are rich in flavonoids, alkaloids, saponins, tannins, glycosides and triterpenoids. The total flavonoid content of the ethyl acetate fraction was $46.28 \mu \mathrm{g} \mathrm{QE} / \mathrm{mg}$ extract. The GC-MS analysis revealed nine major compounds that constituted the crude drug and potentially had a role in reported activities. The crude extract was the most active amongst all the fractions against the bacterial and fungal strains used such that it inhibited the growth of $P$. aeruginosa with a zone of 13 $\mathrm{mm}$ and a MIC value of $16 \mu \mathrm{g} / \mathrm{ml}$ as compared to the standard cefixime, which inhibited the zone by only $10 \mathrm{~mm}$ and a MIC value of $32 \mathrm{\mu g} / \mathrm{ml}$. The highest antioxidant potential in DPPH assay was shown by the crude extract with 91.948\% free radical scavenging activity. The bring shrimps lethality potential of the crude extract was the highest, with a $L D_{50}$ value of $47.635 \mu \mathrm{g} / \mathrm{ml}$. The ethyl acetate fraction inhibits $91.36 \%$ of alpha glucosidase enzyme at a concentration of $0.5 \mathrm{mg} / \mathrm{ml}$. In case of acetylcholine esterase inhibition assay, the methanol fraction inhibits 58.26\% of the enzyme activity. Similarly, for butyrylcholine esterase inhibition, the maximum inhibitory effect was seen in the methanol fraction, with a percentage inhibition of $47.32 \%$.
\end{abstract}

Conclusion: These test results support traditional medicinal uses of the plant. Dryopteris ramosa could be imperative for being used as a therapeutic agent and the medicinal importance of this plant should be further investigated.

Keywords: D. ramosa, Antibacterial, Antifungal, Cytotoxic, Antioxidant, Enzyme inhibition

\footnotetext{
* Correspondence: alamfiaz@cuiatd.edu.pk

'Department of Pharmacy, COMSATS University Islamabad, Abbottabad Campus-22060, Pakistan

Full list of author information is available at the end of the article
}

(c) The Author(s). 2021 Open Access This article is licensed under a Creative Commons Attribution 4.0 International License, which permits use, sharing, adaptation, distribution and reproduction in any medium or format, as long as you give appropriate credit to the original author(s) and the source, provide a link to the Creative Commons licence, and indicate if changes were made. The images or other third party material in this article are included in the article's Creative Commons licence, unless indicated otherwise in a credit line to the material. If material is not included in the article's Creative Commons licence and your intended use is not permitted by statutory regulation or exceeds the permitted use, you will need to obtain permission directly from the copyright holder. To view a copy of this licence, visit http://creativecommons.org/licenses/by/4.0/. The Creative Commons Public Domain Dedication waiver (http://creativecommons.org/publicdomain/zero/1.0/) applies to the data made available in this article, unless otherwise stated in a credit line to the data. 


\section{Background}

Pteridophytes (ferns and its allies) are reported to have medicinal uses and are locally used. The exploration and isolation of active constituents of which is yet to be done [1]. According to The National Aeronautics and Space Administration (NASA) and Korea Rural Development Administration (KRDA), ferns purifies the air from volatile organic compounds (VOCs), viz., Nephrolepis obliterate and Nephrolepis exaltata, commonly called Boston fern and Kimberly queen fern, respectively. There are around 12,000 recognized species of ferns worldwide and play a vital role as folk medicine. Among the 12,000 species, only 131 exist in Pakistan [2]. They are widely distributed in Himalayas [3, 4]. The ethnobotany of fern shows its importance as food, dye, bio-fertilizers, biogas production and medicinal source [5]. Dryopteris ramosa locally known as kunji or pakha is found in moist and shady places at high altitude. The fronds of $D$. ramosa are edible and orally administered for producing antibiotic as well as aphrodisiac effect. They are also used as astringent and febrifuge, as a pesticide. This study was designed to evaluate the medicinal plant $D$. ramosa for various phytochemical and biological activities to explore its potential use in traditional medicines.

\section{Methods}

\section{Collection of plant material}

The plant was collected from Galyat, Pakistan. Identified by a botanist, Dr. Manzoor Hussain and was placed in the herbarium at the botany department of Hazara University Mansehra with voucher specimen no. (BDHUD.R-088/17). After identification, the plant was thoroughly washed with water and shade dried. Once completely dried, the plant was ground to fine powder. The powder was macerated in methanol (twice distilled) for 21 days, at room temperature such that the material was shaken and mixed twice a day. After the completion of 21 days period, the solvent was filtered from the macerated residue of the plant powder using muslin cloth, followed by filtration twice through filter paper. After filtration, the solvent was concentrated using rotary vacuum evaporator at $40 \mathrm{C}$. Once concentrated, it was allowed to be completely dried at room temperature and the weight of the crude methanolic extract was calculated. Different fractions of the crude extract were made by using liquid-liquid extraction with solvents in the increasing order of polarity such as ethyl acetate, methanol and water [6]. The crude extract was re-dissolved in distilled water and extracted with the solvents using a separating funnel. The crude fraction along with the solvent was shaken vigorously in the separating funnel and the layers were allowed to separate out. Once the layers were completely separated, the desired layer in the funnel was collected and concentrated. After concentration, each fraction was properly labelled, allowed to dry and stored in the refrigerator along with the crude fraction.

\section{Antibacterial assay}

The antibacterial potential of the extracts was determined by agar well diffusion method by protocols already mentioned in literature [7]. Following organisms were used in the study: Methicillin resistant Staphylococcus aureus-10 (ATCC 33591), Methicillin resistant Staphylococcus aureus-11 (ATCC 29213), Escherichia coli (ATCC 15224), Pseudomonas aeruginosa (ATCC 9721) and Staphylococcus aureus (ATCC 6538). For the preparation of nutrient agar, $28 \mathrm{~g}$ of agar was dissolved in $1000 \mathrm{ml}$ of distilled water. The media was autoclaved and poured into petri plates under sterile conditions. The plant extract samples were prepared by dissolving $20 \mathrm{mg}$ of the extract in 1 $\mathrm{ml}$ of DMSO. Cefixime with the concentration as 1 $\mathrm{mg} / \mathrm{ml}$ of DMSO was used as the control whereas, DMSO was the negative control.

After the formation of bacterial lawns, wells were made into the agar using cork borer. Each well was sealed using $20 \mu \mathrm{L}$ of the agar. After sealing, $40 \mu \mathrm{L}$ of each extract were added in each well. The plates were then allowed to incubate at $37 \mathrm{C}$ for $24 \mathrm{~h}$. The experiments were run in triplicates. The zones of inhibition for extracts with good antimicrobial activity were determined in $\mathrm{mm}$.

\section{Antifungal assay}

The antifungal potential of the extracts was determined by agar well diffusion method by protocols already mentioned in literature on the selected strains of Candida albicans and Candida kefyr [7].

The plant extract samples were prepared by dissolving $20 \mathrm{mg}$ of the extract in $1 \mathrm{ml}$ of DMSO. Clotrimazole with the concentration as $1 \mathrm{mg} / \mathrm{ml}$ of DMSO was the positive control while DMSO was the negative control. For the preparation of sabouraud dextrose agar, $65 \mathrm{~g}$ of agar was dissolved in $1000 \mathrm{ml}$ of distilled water. The media was autoclaved and poured into petri plates under sterile conditions. After the formation of fungal lawns, wells were made into the agar using cork borer. Each well was sealed using $20 \mu \mathrm{L}$ of the agar. After sealing, $40 \mu \mathrm{L}$ of each extract were added in each well. The plates were then allowed to incubate at $37 \mathrm{C}$ for $24 \mathrm{~h}$. The experiments were run in triplicates. The zones of inhibition for extracts with good antifungal activity were determined in $\mathrm{mm}$.

\section{Antioxidant assay}

DPPH free radical scavenging assay was applied to assess the antioxidant capacity of the plant extracts by following protocols with little alteration [8]. For the plant 
extracts, $2 \mathrm{mg}$ of each extract was mixed with $1 \mathrm{ml}$ DMSO and placed on the vortex mixer for $10 \mathrm{~min}$ in order for proper mixing. For DPPH solution, $3.94 \mathrm{mg}$ of DPPH was dissolved in $100 \mathrm{ml}$ methanol hence $100 \mathrm{ml}$ of $0.1 \mathrm{mM}$ DPPH solution was acquired. One milliliter of the sample solution was mixed in $2 \mathrm{ml}$ of $0.1 \mathrm{mM}$ solution of DPPH and incubated for $30 \mathrm{~min}$, in dark, at room temperature. After incubation, the absorbance was measured at $517 \mathrm{~nm}$ using UV spectrophotometer. The process was repeated three times and the percentage radical scavenging activity was determined as follows:

Radical scavenging $\%=$ Apc-As $/$ Apc $\times 100$

$(\mathrm{Apc}=$ absorbance of the positive control;

As $=$ absorbance value of sample solution).

\section{Brine shrimp lethality assay}

The cytotoxic assay of the plant extract was performed using brine shrimp lethality test with slight alteration [9]. Artificial sea water was made by dissolving $38 \mathrm{~g}$ of sea salt in $1 \mathrm{l}$ of distilled water. The $\mathrm{pH}$ of this solution was maintained at 8.5. The plant extracts were made such that $5 \mathrm{mg}$ of each extract was dissolved in $5 \mathrm{ml}$ of methanol. A two chambered assembly that had a perforated wall between the two compartments was filled with artificial sea water. In on chamber, the brine shrimp eggs were placed and this compartment was covered with aluminum foil in order to retain darkness. The assembly was left for $48 \mathrm{~h}$ at $28 \mathrm{C}$ ensuring no disturbance. To the other side of the compartment, a lamp was placed so that the hatched nauplii move towards the light and were collected. $5 \mathrm{mg} / 5 \mathrm{ml}$ methanol solutions were made of each sample, of which 1000, 100 and 10 ppm dilutions were taken in test tubes in triplicate. After complete evaporation of methanol in each test tube, 10 nauplii along with $4.5 \mathrm{ml}$ of sea water was taken and incubated for $24 \mathrm{~h}$. Sufficient oxygen and humidity conditions were maintained in the incubator. After $24 \mathrm{~h}$ of incubation, number of dead nauplii were counted and the $\mathrm{LD}_{50}$ value of the extract was determined using probit analysis software [10].

\section{Phytochemical analysis}

The phytochemical analysis of different fractions of the fronds was carried out in order to determine their qualitative and quantitative profile. The qualitative identification tests of the crude methanolic extract was carried out by using standard protocols with slight modification in the procedure $[11,12]$. Total flavonoid content were determined by using the aluminum chloride calorimetric method, the total flavonoid content (TFC) of the extracts were determined by the previously described assays with slight modification [13].

\section{Acetylcholine esterase inhibition assay}

The inhibition potential of the extracts against acetylcholine esterase enzyme was determined with slight modification in the protocols according to system availability [14].

The enzyme was dissolved in the phosphate buffer such that to make the concentration as 0.005 units per $\mathrm{ml}$. The enzyme solution was then stored at $-80 \mathrm{C}$. the test samples were dissolved in DMSO to obtain $20 \mathrm{mM}$ solution. The extracts were diluted using sodium phosphate buffer.

\section{Butyrylcholine esterase inhibition assay}

The inhibition potential of the extracts against acetylcholine esterase enzyme was determined with slight modification in the protocols according to system availability [15]. The enzyme was dissolved in the phosphate buffer such that to make the concentration as 0.005 units per $\mathrm{ml}$. The enzyme solution was then stored at $-80 \mathrm{C}$. the test samples were dissolved in DMSO to obtain 20 $\mathrm{mM}$ solution. The extracts were diluted using sodium phosphate buffer.

\section{Alpha glucosidase inhibition assay}

The alpha glucosidase activity was carried out according to the previously employed protocol with some modifications [16]. DMSO was used as a solvent to dissolve the samples. The enzyme solution with following composition was prepared fresh; $\alpha$-glucosidase $(0.8$ units $/ \mathrm{ml})$ in $50 \mathrm{mM}$ phosphate buffer (pH 7), substrate pNP-G $(0.7$ $\mathrm{mM}$ ) in phosphate buffer and $100 \mathrm{mM} \mathrm{NaCl}$. The mixture was kept cool during the test. $20 \mu \mathrm{L}$ of test solution and $80 \mu \mathrm{L}$ of enzyme solution were incubated for $5 \mathrm{~min}$ at $37^{\circ} \mathrm{C} .1 .9 \mathrm{~mL}$ of substrate solution was introduced to initiate the reaction and placed for incubation for further $15 \mathrm{~min}$. To stop the reaction $0.5 \mathrm{M}$ Tris solution $(2 \mathrm{~mL})$ was mixed. The pNP (p-nitrophenol) formed during the reaction showed absorbance at $400 \mathrm{~nm}$. DMSO $(20 \mu \mathrm{L})$ acted as a blank. The results were compared with standard drug Acarbose. The $\alpha$-glucosidase inhibition in percent was calculated by $=100-(\mathrm{AB}-\mathrm{AS}) / \mathrm{AB}$ Where $\mathrm{AB}=$ absorbance of blank, AS = absorbance of the sample.

\section{GC-MS analysis}

The GC-MS study of the crude extract of the fronds was done by the protocols already available in literature with slight modification [17].

$50 \mathrm{mg}$ of D. ramosa was extracted with methanol and added few drops of $\mathrm{KOH}$ and centrifuged for $10 \mathrm{~min}$. The supernatant was analyzed on GC-MS. The instrument used as Perkin-Elmer GC Claurus 500 equipped with Elite-1 fused silica capillary column. Ionization source used as $70 \mathrm{eV}$. Helium was used as a carrier gas. The flow rate was $1 \mathrm{~mL} / \mathrm{min}$. Injection volume was $0.5 \mu \mathrm{L}$. 
Injection temperature was $250{ }^{\circ} \mathrm{C}$ and of that of Ion source was $280^{\circ} \mathrm{C}$. The program was set as: oven temperature was held for $2 \mathrm{~min}$ at $110^{\circ} \mathrm{C}$ at rate of $20^{\circ} \mathrm{C} / \mathrm{min}$ to $200{ }^{\circ} \mathrm{C}$ and then then at $5^{\circ} \mathrm{C} / \mathrm{min}$ to $280{ }^{\circ} \mathrm{C}$ held for $5 \mathrm{~min}$. The run time was $40 \mathrm{~min}$. The compounds were identified using NIST library by comparing the mass spectrum fragmentation patterns.

\section{Results and discussions}

\section{Phytochemicals in fronds}

The phytochemical analysis of the crude extract showed that secondary metabolites such as alkaloids, saponins, tannins, flavonoids, carbohydrates, triterpenes, phenols and glycosides are found to constitute the phytochemical profile of the fronds Table 1 . The qualitative phytochemical analysis of the crude methanolic extract of Dryopteris ramosa fronds revealed the presence of phytochemicals such as flavonoids, saponins, glycosides, triterpenoids and tannins etc. Our study is in correspondence to a previously conducted study in which a number of plants were analyzed for their phytochemical constituents. Other than this organoleptic study was also carried out which can be helpful in the detection of adulterations and can confirm the authenticity of the intact of powdered drug and drug product. The ethno-pharmacological use of Dryopteris ramosa reveals that its phytochemical constituents are responsible for the subsiding of various ailments [18].

\section{Total flavonoid content}

The total flavonoid content (TFC) of the different solvent fractions of crude extract was determined and their standard error mean was also determined. The results indicated that the ethyl acetate fraction showed the highest flavonoid content of $45.28 \mu \mathrm{g} \mathrm{QE} / \mathrm{mg}$ of the extract with a standard error mean of \pm 1 .67. Similarly, the methanolic fraction consists of $36.94 \mu \mathrm{g} \mathrm{QE} / \mathrm{mg}$ of flavonoids with a standard error mean value of \pm 1.85 . The water fraction, as compared to the other fractions showed the lowest value of TFC, with a value of 25.69 $\mu \mathrm{gQE} / \mathrm{mg}$ with a standard error mean as \pm 1.52 (Fig. 1). The total flavonoid content (TFC) is an indicator of the quantitative measure of the flavonoids present in a sample. The total flavonoid content of the fronds showed that they are rich in flavonoids, especially the ethyl acetate fraction of the crude extract with a TFC value of $46.28 \mu \mathrm{g} \mathrm{QE} / \mathrm{mg}$ of extract.

\section{a- glucosidase inhibition assay}

At a concentration of $0.5 \mathrm{mg} / \mathrm{ml}$, the ethyl acetate fraction of the fronds inhibited $91.36 \%$ of the enzyme activity with a standard error mean of \pm 1.94 . This was followed by the methanol fraction, in which the percentage inhibition was $75.54 \%( \pm 1.83)$. The water fraction however inhibited only $41.35 \%( \pm 1.75)$ of enzyme. The $\mathrm{IC}_{50}$ value calculated for the ethyl acetate fraction was $156.28( \pm 1.75) \mu \mathrm{g} / \mathrm{ml}$. whereas methanol fraction showed $\mathrm{IC}_{50}$ value of $167.42 \mu \mathrm{g} / \mathrm{ml}( \pm 1.59)$. Acarbose, as the standard showed $\mathrm{IC}_{50}$ value of $38.1 \mu \mathrm{g} / \mathrm{ml}( \pm 1.25)$ (Fig. 2).

The major enzyme in the assimilation of sugars is alpha-glucosidase enzyme and its inhibitors restrict the postprandial hyperglycemia by impeding the freedom of D-glucose of oligosaccharides and disaccharides from dietary complex starches and in this manner postpone the glucose ingestion [19]. It is important to scan for successful and safe alpha-glucosidase inhibitors from

Table 1 Qualitative phytochemical analysis of crude extract of D. ramose

\begin{tabular}{|c|c|c|c|c|}
\hline Sr. No. & Phytochemical & Test & Observations & Inference \\
\hline 1 & Saponins & Froth test & Foam formation & + \\
\hline \multirow[t]{3}{*}{2} & Flavonoids & Shinoda test & Red or pink color & + \\
\hline & & Alkaline reagent test & Yellow color & + \\
\hline & & $\mathrm{AlCl}_{3}$ test. & Yellow ppt & + \\
\hline \multirow[t]{3}{*}{3} & Alkaloids & Dragendroff reagent & Reddish brown ppt & + \\
\hline & & Mayer reagent & Creamy ppt & + \\
\hline & & Wagner reagent & Reddish brown ppt & + \\
\hline 4 & Carbohydrate & Fehling's test & Brick red ppt & + \\
\hline \multirow[t]{3}{*}{5} & Glycosides & Keller-Killiani test & Brown ring at interface & + \\
\hline & & Legal's test & Pink to red color & + \\
\hline & & Borntrager's test & Reddish pink color & + \\
\hline 6 & Triterpenes & Salkowaski test & Reddish brown color & + \\
\hline 7 & Phenols & $\mathrm{FeCl}_{3}$ test & Color change & + \\
\hline \multirow[t]{2}{*}{8} & Tannins & $\mathrm{FeCl}_{3}$ test & Black color & + \\
\hline & & Gelatin test & Green black & + \\
\hline
\end{tabular}




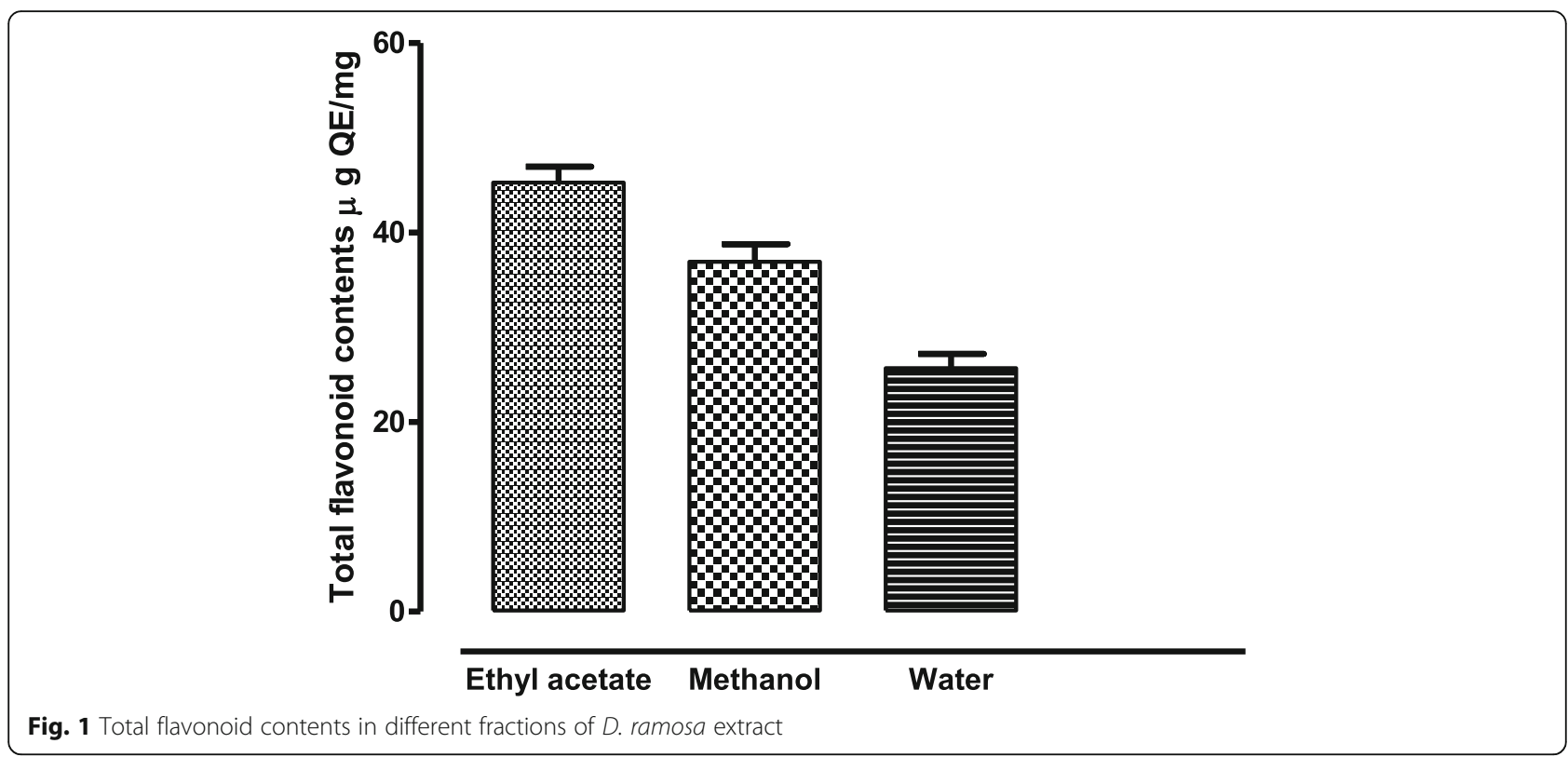

natural sources, so as to create antidiabetic drugs. In our findings, the ethyl acetate fraction of the fronds inhibited $91.36 \%$ of the enzyme activity. This was followed by the methanolic fraction, in which the percentage inhibition was 75.54. However, the water fraction showed only $41.35 \%$ inhibition of the enzyme.

\section{Acetylcholine esterase inhibition assay}

The methanol fraction exhibited the best acetylcholine esterase inhibition activity, by inhibiting $58.26( \pm 1.95) \%$ of the enzyme at a concentration of $0.5 \mathrm{mg} / \mathrm{ml}$. The percentage inhibition recorded for the ethyl acetate and water fractions was $29.75( \pm 1.05) \%$ and $15.92( \pm 0.65) \%$ respectively. Eserine was used as a standard that inhibited $91.27( \pm 1.99) \%$ of the enzyme activity. $\mathrm{IC}_{50}$ value calculated for the methanolic fraction was $349.82 \mu \mathrm{g} / \mathrm{ml}$ whereas, for eserine it was $0.04 \mu \mathrm{g} / \mathrm{ml}$ (Fig. 3).

\section{Butyrylcholine esterase inhibition assay}

None of the fractions inhibited butyrylcholine esterase enzyme with a significant value. The inhibition shown by the extracts at a concentration of $0.5 \mathrm{mg} / \mathrm{ml}$ was $47.32( \pm 1.3) \mu \mathrm{g} / \mathrm{ml}, 35.26( \pm 0.95) \mu \mathrm{g} / \mathrm{ml}$ and $15.45( \pm$ $0.60) \mu \mathrm{g} / \mathrm{ml}$ for methanolic, water and ethyl acetate fraction respectively (Fig. 4). Acetylcholinesterase (AChE) and butyryl cholinesterase (BChE) are an important group of enzymes that are involved in the termination of

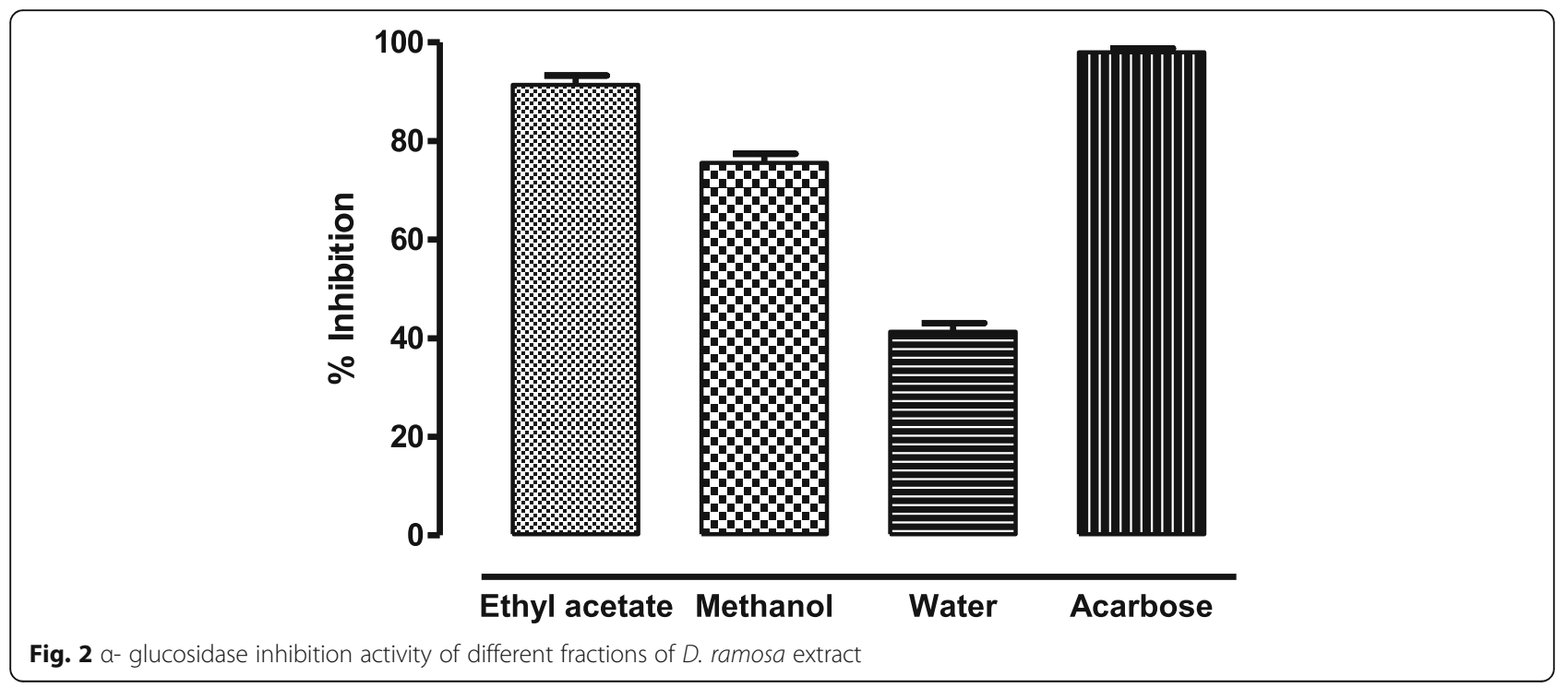




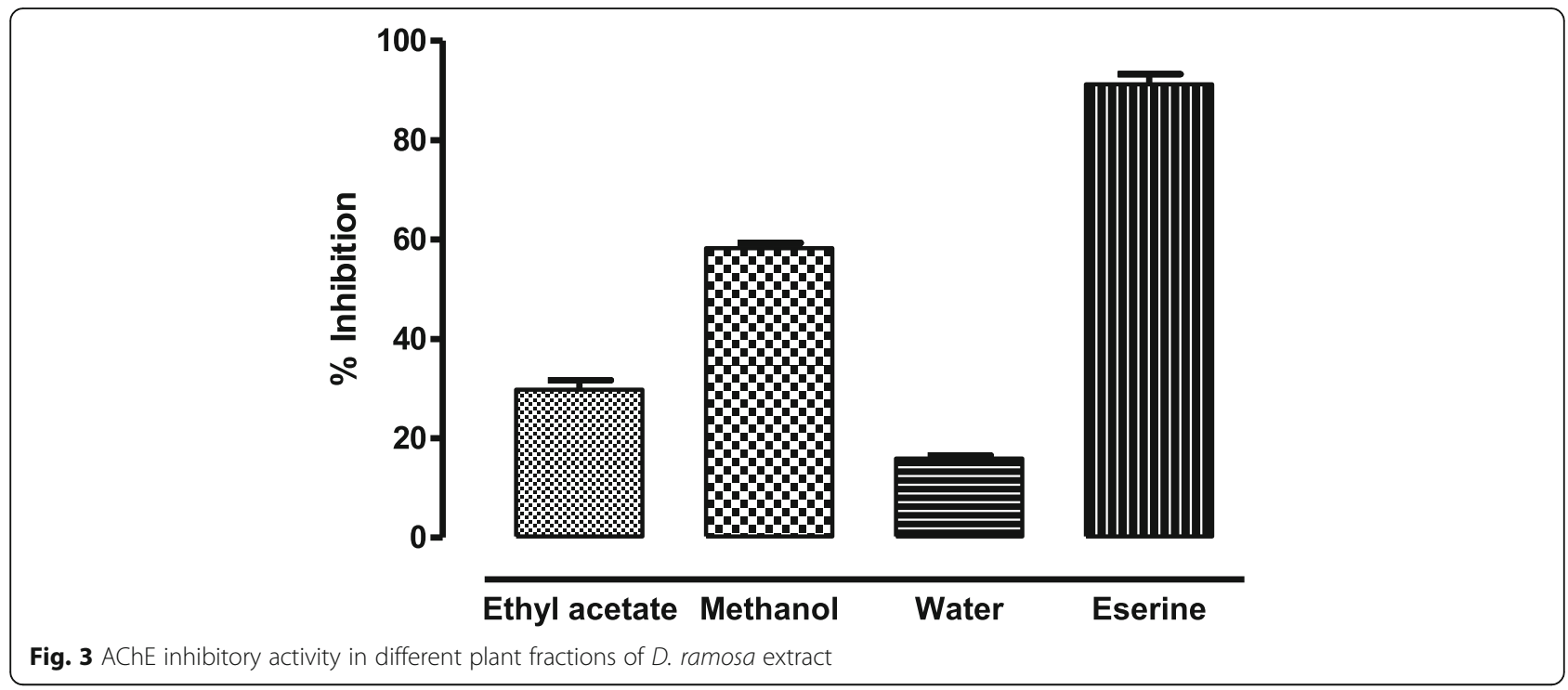

synaptic transmission. The activity was performed against various fractions of the plant. At a concentration of $0.5 \mathrm{mg} / \mathrm{ml}$, the methanol fraction of fronds exhibited the best acetylcholine esterase inhibition activity. However, none of the extracts inhibited the BChE significantly.

\section{Antibacterial assay}

In case of antibacterial assay, different fractions were active against different strains and the zones of inhibition varied. The ethyl acetate fraction showed no activity against any of the bacterial strains. In case of the methanol fraction, a significant zone of $12 \mathrm{~mm}$ was produced against MRSA-10 strain, compared to the standard cefixime, in which the zone was only $10 \mathrm{~mm}$. Similarly, against $E$. coli, the zone produced by the methanolic fraction was $8 \mathrm{~mm}$. The water fraction produced a $12 \mathrm{~mm}$ inhibition zone against MRSA-10, as compared to $10 \mathrm{~mm}$ given by the standard and $6 \mathrm{~mm}$ zone against $S$. aureus. The crude extract was the most active, amongst all the fractions, against $P$. aeruginosa, where it exhibited a zone of $13 \mathrm{~mm}$ while the standard produced a zone of $11 \mathrm{~mm}$. DMSO being the negative control did not inhibit the zones. The MIC was calculated for all the extracts. According to the results, the lowest MIC was shown by the crude extract against $P$. aeruginosa, with a MIC value of $16 \mu \mathrm{g} / \mathrm{ml}$, as compared to the standard cefixime, which gave a MIC of $32 \mu \mathrm{g} / \mathrm{ml}$. Similarly, against MRSA-10, the methanolic and water fraction have a MIC of $32 \mu \mathrm{g} / \mathrm{ml}$, as compared to the MIC of cefixime that was $64 \mu \mathrm{g} / \mathrm{ml}$ (Fig. 5).

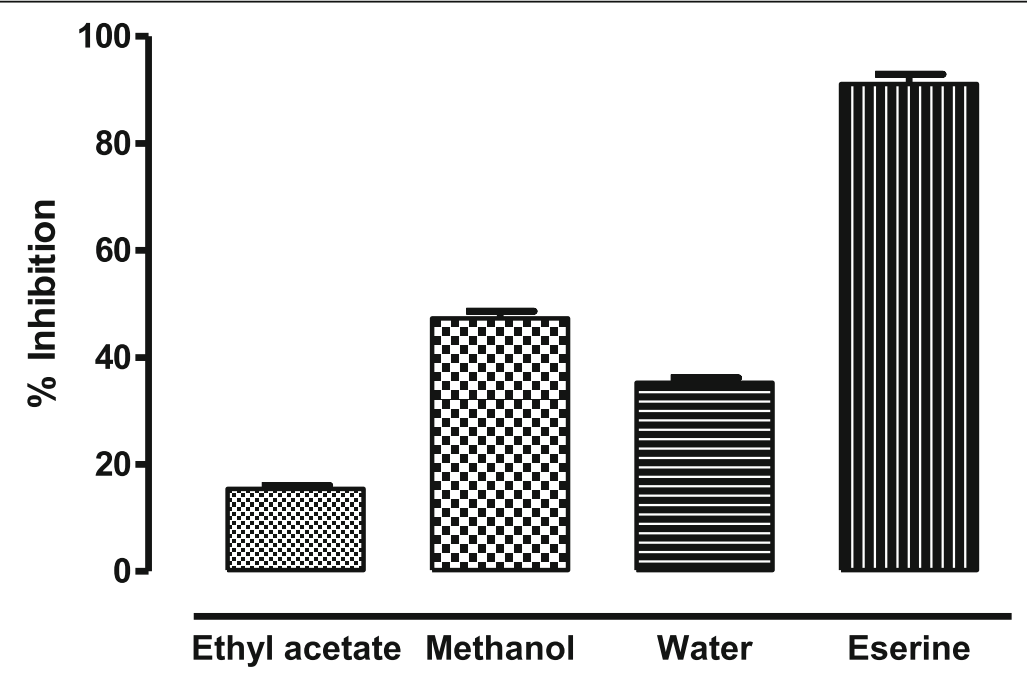

Fig. 4 Percent inhibition of butyryl cholinesterase activity present in different fractions of $D$. ramosa extract 


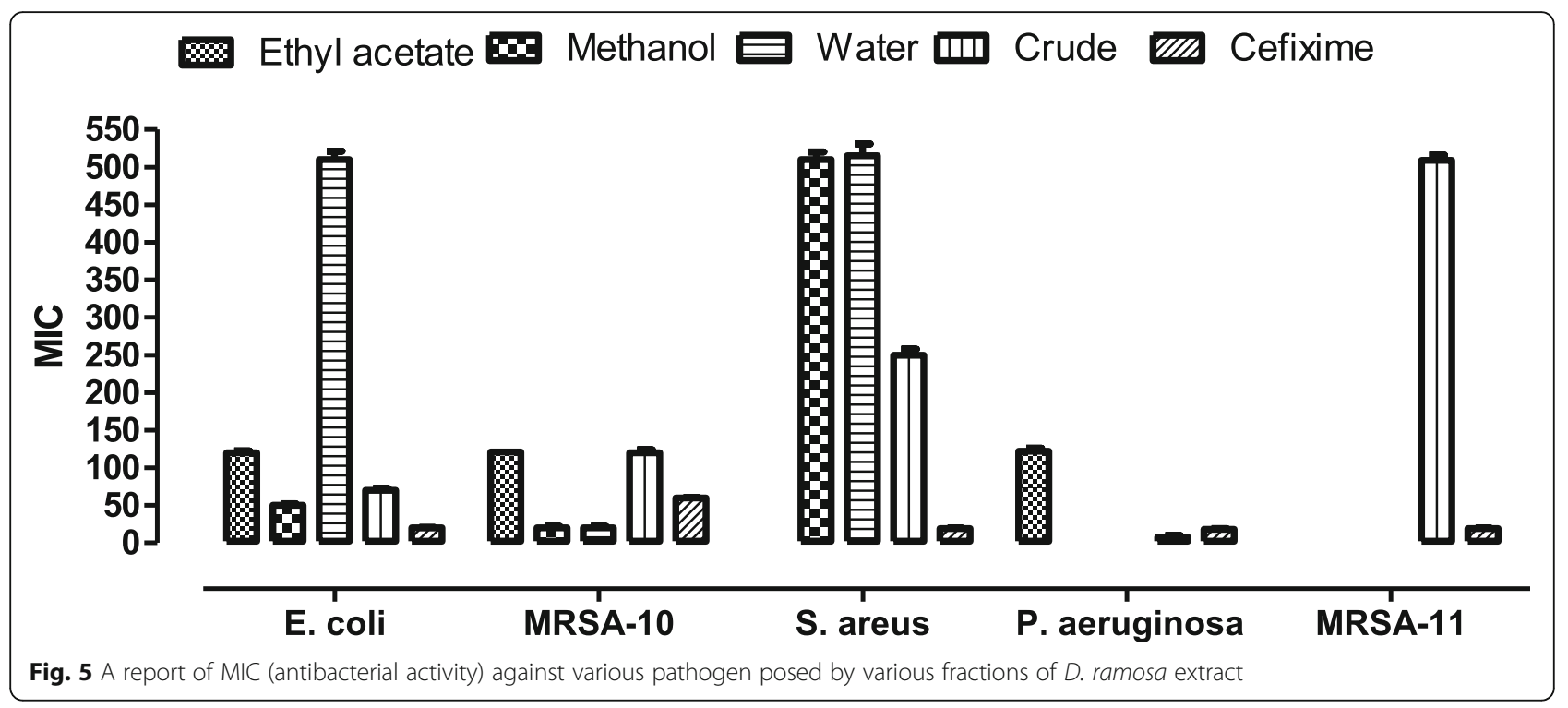

\section{Antifungal assay}

As compared to the antibacterial results, the antifungal results exhibited by the extracts were insignificant. Clotrimazole as standard inhibited the two fungal strains, $C$. albicans and C. kefyr, by producing an inhibiting zone of $20 \mathrm{~mm}( \pm 0.8)$ and $18 \mathrm{~mm}( \pm 0.6)$ respectively (Fig. 6). The antifungal activity exhibited by all the fractions, as well as the crude extract were insignificant, however, the antibacterial potential of the extracts was comparatively significant.

\section{Antioxidant assay}

According to the DPPH assay, the crude extract exhibited the highest free radical scavenging potential of 91.948\% ( \pm 1.3$)$, followed by the methanol fraction with the inhibitory percentage of $88.25 \%( \pm 1.1)$. The water and ethyl acetate fractions had the percentage inhibition potential of $87.283 \%( \pm 1.5)$ and $69.974 \%( \pm 0.83)$ respectively (Fig. 7). Flavonoids and phenols are medicinally essential and are available as significant constituents in plants. They are generally viewed as in charge of antioxidant potential and in this way assessed for the most part for this reason. There are numerous reports that antioxidant potentials of plants are because of the nearness of phenolic compounds [20, 21]. The antioxidant potential of Dryopteris ramosa was determined using DPPH assay. According to the results, the crude extract exhibited the highest value of free radical scavenging potential, followed by the methanol fraction, water and ethyl acetate fraction.

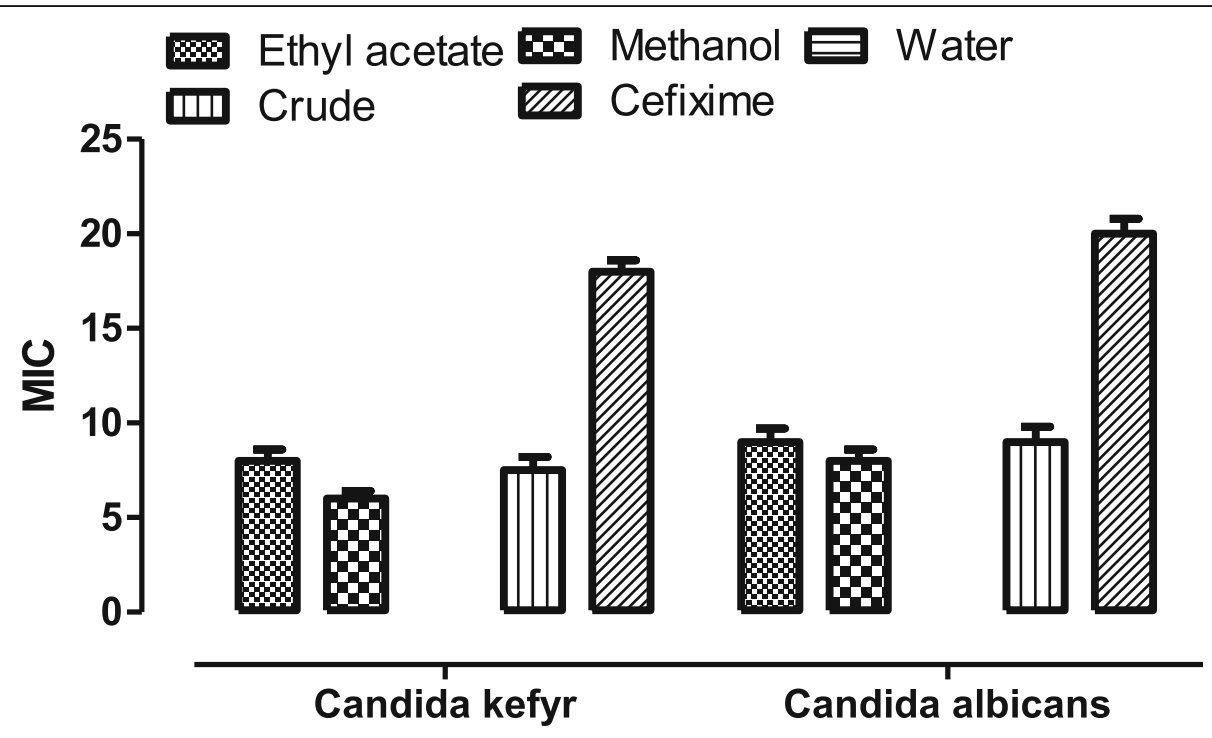

Fig. 6 A report of antifungal activity against various pathogen showed by various fractions of plant extract 


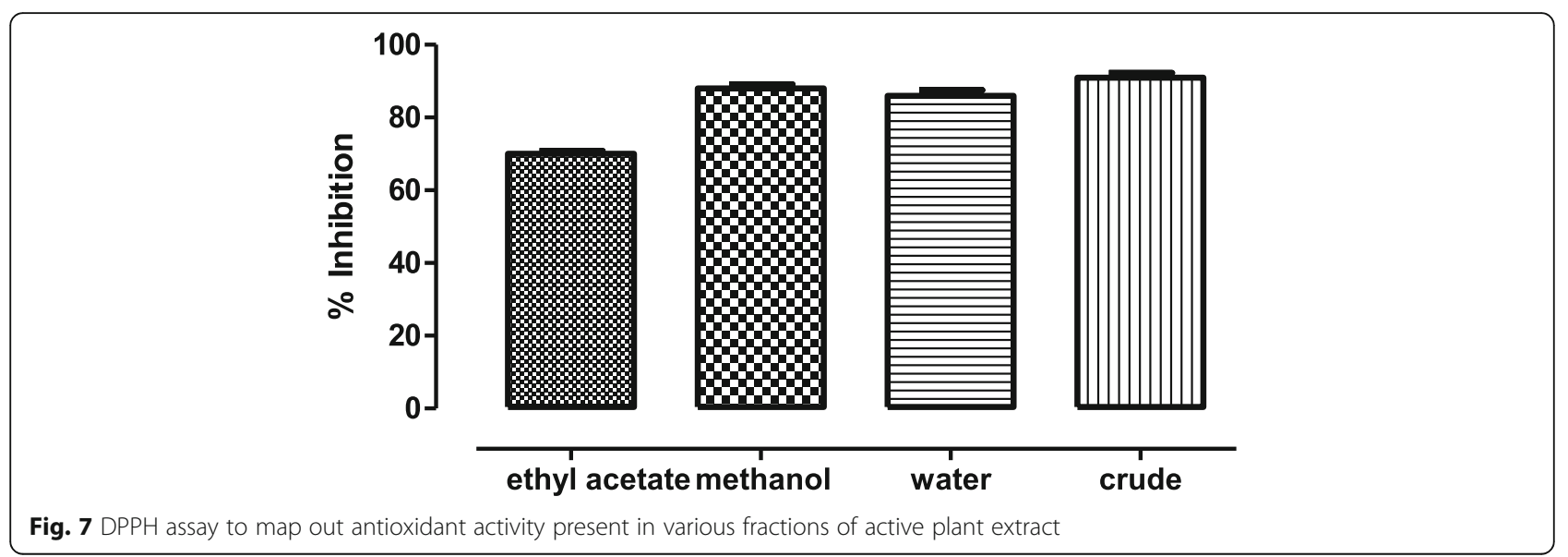

\section{Brine shrimp lethality assay}

For the lethality assay, the number of nauplii killed by the extracts were determined in order to calculate the $\mathrm{LD}_{50}$ values for the extracts. Methanol fraction, with a $\mathrm{LD}_{50}$ value of $47.63 \mu \mathrm{g} / \mathrm{ml}$ was determined to be the most toxic fraction amongst all. Whereas, the water fraction was comparatively the least toxic, with a $\mathrm{LD}_{50}$ value of $422.61 \mu \mathrm{g} / \mathrm{ml}$. The order of lethality was water < ethyl acetate < crude extract < methanol. For the determination of the lethality of the extracts, brine shrimps' assay was performed. The methanol fraction was found to be the most lethal fraction, whereas the water fraction was the least toxic fraction, as indicated by the brine shrimp assay.

\section{GC-MS analysis}

The phytochemical constituents of the crude extract of Dryopteris ramosa were identified by using gas chromatography-mass spectrometry (GC-MS). The results of our GC-MS analysis indicated the presence of 9 compounds; 1-decene, 9-Methyl; Decane; 2-Heptane isothiocyanate; Heptyl octacosyl ether; Trichloroacetic acid, hexadecyl ester; Nonadecane, 1-chloro; Distearyl sulphide; 2-Methyltetracosan and 3-Butyl-2-nitrohept-1- ene. The identified compounds were found to be active pharmacologically. The isothiocyanate compounds has shown promising cholinesterase inhibitory activity previously [22]. Another compound identified by GC-MS was heptyl octacosyl ether which was reported to have strong antioxidant activity [23]. Similarly, trichloro acetic acid has application as safe agent for acne scars by its cytotoxic action [24]. Hexadecyl ester like compounds are reported to have a role as antimicrobial agent against uncomplicated UTI infection but the studies were not conclusive [25]. Nonadecane and related compounds reported to be the part of extracts previously tested for antioxidant and antimicrobial activity [26]. Distearyl sulphide and related compounds isolated from mangrove are reported to have bactericidal, insecticidal and fungicidal activities [27]. A complete description of the components obtained from GC-MS analysis was summarized in Table 2.

\section{Conclusions}

Dryopteris ramosa has numerous potentials uses that are consolidated in the treatment of different maladies as old traditional medication. The results distinctly demonstrated that the ethyl acetate fraction of the fronds

Table 2 GC-MS analysis of extract of Dryopteris ramosa with retention time of different compounds

\begin{tabular}{llll}
\hline Retention time (min) & Compound name & Molecular formula & Molecular weight \\
\hline 6.020 & 1-decene, 9-Methyl & $\mathrm{C}_{11} \mathrm{H}_{22}$ & 154 \\
6.190 & Decane & $\mathrm{C}_{10} \mathrm{H}_{22}$ & 142 \\
7.060 & 2-Heptane isothiocyanate & $\mathrm{C}_{8} \mathrm{H}_{15} \mathrm{NS}$ & 157 \\
21.171 & Heptyl octacosyl ether & $\mathrm{C}_{35} \mathrm{H}_{72} \mathrm{O}$ & 508 \\
22.162 & Trichloroacetic acid, hexadecyl ester & $\mathrm{C}_{18} \mathrm{H}_{33} \mathrm{O}_{2} \mathrm{Cl}_{3}$ & 386 \\
22.962 & Nonadecane, 1-chloro & $\mathrm{C}_{19} \mathrm{H}_{39} \mathrm{Cl}$ & 302 \\
26.708 & Distearyl sulphide & $\mathrm{C}_{36} \mathrm{H}_{74} \mathrm{~S}$ & 538 \\
32.101 & 2-Methyltetracosan & $\mathrm{C}_{25} \mathrm{H}_{52}$ & 352 \\
32.741 & 3-Butyl-2-nitrohept-1-ene & $\mathrm{C}_{11} \mathrm{H}_{21} \mathrm{O}_{2} \mathrm{~N}$ & 199 \\
\hline
\end{tabular}


possesses the highest TPC value. The methanol fraction inhibits the alpha glucosidase enzyme such that the percentage inhibition can be regarded as a good activity. Similarly, the methanol fraction inhibits the AChE by marginally good percentage. Dryopteris ramosa crude extract demonstrated significant outcomes in the repression of cholinesterase enzyme. The crude extract showed the highest activity against $P$. aeruginosa so it could prove as a significant alternative in the treatment and prevention of diseases like meningitis, pneumonia etc. The antifungal potential of the plant is significantly low. The crude extract exhibits the highest antioxidant potential. Despite of all the activities given by the methanol fraction, it is the most lethal fraction, as revealed by the cytotoxic assay. As our results of investigation of Dryopteris ramosa uncovered the presence of large scale of significant elements in GC-MS analysis, this plant could be imperative for being used as a therapeutic agent. Therefore, the medicinal importance of this plant should be further investigated.

\section{Abbreviations \\ D. ramosa: Dryopteris ramosa; GC-MS: Gas chromatography mass spectrometery; DPPH: 2,2-Diphenyl-1-picrylhydrazyl; MIC: Minimum inhibitory concentration; BChE: Butyrylcholinesterase enzyme; AChE: Acetylcholine esterase enzyme; TFC: Total flavonoid contents; pNP: P-nitrophenol; DMSO: Dimethyl sulphoxide}

\section{Acknowledgements}

Not Applicable.

\section{Authors' contributions}

FA Supervisor, Desgined the experiment, Prepared the manuscript; SHAS performed the experiments, MHHBA analysed the results and statistics. All authors have gone through and approved the manuscript. All authors have agreed both to be personally accountable for the author's own contributions and to ensure that questions related to the accuracy or integrity of any part of the work.

\section{Funding}

No funding to disclose.

\section{Availability of data and materials}

The datasets used and/or analysed during the current study are available from the corresponding author on reasonable request.

\section{Declarations}

\section{Ethics approval and consent to participate}

The experiments on plant extract were compiled and approved by the Research Ethical Committee (REC) Number: PHM-Eth-/CF-M04/11-24, of COMSAT University, Islamabad, Abbottabad Campus. Plant is freely available and used by local people as food and there is no constraint by the authority to collect the plant.

\section{Consent for publication}

All the author's consents were taken for publication of this manuscript.

\section{Competing interests}

All authors in this article declare no conflict of interest.

\section{Author details}

'Department of Pharmacy, COMSATS University Islamabad, Abbottabad Campus-22060, Pakistan. ${ }^{2}$ Department of Genetics, Institute of Fundamental Medicine and Biology, Kazan Federal University, 420008 Kazan, Russia.
Received: 11 March 2021 Accepted: 29 June 2021

Published online: 08 July 2021

\section{References}

1. Parihar P, Parihar L. Some pteridophytes of medicinal importance from Rajasthan. Nat Prod Rad. 2006;4:297-301.

2. Iqbal S, Yousaf M, Younus M. A field survey of mycorrhizal associations in ferns of Pakistan. New Phytol. 1981;87(1):69-79. https://doi.org/10.1111/j.14 69-8137.1981.tb01691.x.

3. Singh M, Singh N, Khare P, Rawat A. Antimicrobial activity of some important Adiantum species used traditionally in indigenous systems of medicine. J Ethnopharmacol. 2008;115(2):327-9. https://doi.org/10.1016/j. jep.2007.09.018.

4. Sharma B, Vyas M. Ethnobotanical studies on the ferns and fern allies of Rajasthan. Nelumbo. 1985:27(1-4):90-1.

5. Talukdar AD, Tarafdar RG, Choudhury MD, Nath D, Choudhury S. A review on pteridophyte antioxidants and their potential role in discovery of new drugs. Assam Univ J Sci Technol. 2011;7(1):151-5.

6. Bala S, Uniyal G, Chattopadhyay S, Tripathi V, Sashidhara K, Kulshrestha M, et al. Analysis of taxol and major taxoids in Himalayan yew, Taxus wallichiana. J Chromatogr A. 1999;858(2):239-44. https://doi.org/10.1016/ S0021-9673(99)00841-9.

7. Balouiri M, Sadiki M, Ibnsouda SK. Methods for in vitro evaluating antimicrobial activity: a review. J Pharm Anal. 2016;6(2):71-9. https://doi. org/10.1016/j.jpha.2015.11.005.

8. Clarke G, Ting KN, Wiart C, Fry J: Radical scavenging, ferric reducing activity potential and Total Phenolics content indicates redundancy in use of all three assays to screen for antioxidant activity of extracts of plants from the Malaysian rainforest. 2013.

9. Olowa LF, Nuñeza OM. Brine shrimp lethality assay of the ethanolic extracts of three selected species of medicinal plants from lligan City, Philippines. Int Res J Biol Sci. 2013;2(11):74-7.

10. Kisangau DP, Hosea KM, Joseph CC, Lyaruu HV. In vitro antimicrobial assay of plants used in traditional medicine in Bukoba rural district, Tanzania. Afr J Tradit Complement Altern Med. 2007;4(4):510-23. https://doi.org/10.4314/a jtcam.v4i4.31245.

11. Singh KL, Bag G. Phytochemical analysis and determination of total phenolics content in water extracts of three species of Hedychium. Int J PharmTech Res. 2013;5(4):1516-21.

12. Vaghasiya Y, Dave R, Chanda S. Phytochemical analysis of some medicinal plants from western region of India. Res J Med Plant. 2011;5(5):567-76. https://doi.org/10.3923/rjmp.2011.567.576.

13. UI-Haq I, Ullah N, Bibi G, Kanwal S, Ahmad MS, Mirza B. Antioxidant and cytotoxic activities and phytochemical analysis of Euphorbia wallichii root extract and its fractions. Iran J Pharm Res. 2012;11(1):241.

14. Dhanasekaran S, Perumal P, Palayan M. In-vitro screening for acetylcholinesterase enzyme inhibition potential and antioxidant activity of extracts of Ipomoea aquatica Forsk: therapeutic lead for Alzheimer's disease. J Appl Pharm Sci. 2015;5(02):012-6.

15. Zhao T, Ding K-M, Zhang L, Cheng X-M, Wang C-H, Wang Z-T. Acetylcholinesterase and butyrylcholinesterase inhibitory activities of $\beta$ carboline and quinoline alkaloids derivatives from the plants of genus Peganum. J Chem. 2013;2013. https://doi.org/10.1155/2013/717232.

16. Telagari $M$, Hullatti $K$. In-vitro $a$-amylase and a-glucosidase inhibitory activity of Adiantum caudatum Linn. and Celosia argentea Linn. extracts and fractions. Indian J Pharmacol. 2015;47(4):425.

17. Abdullah A-SH, Mohammed AS, Abdullah R, Mirghani MES, Al-Qubaisi M. Cytotoxic effects of Mangifera indica L. kernel extract on human breast cancer (MCF-7 and MDA-MB-231 cell lines) and bioactive constituents in the crude extract. BMC Complement Altern Med. 2014;14(1):199.

18. Abbasi AM, Khan MA, Shah MH, Shah MM, Pervez A, Ahmad M. Ethnobotanical appraisal and cultural values of medicinally important wild edible vegetables of lesser Himalayas-Pakistan. J Ethnobiol Ethnomed. 2013; 9(1):66. https://doi.org/10.1186/1746-4269-9-66.

19. Gao H, Huang Y-N, Gao B, Li P, Inagaki C, Kawabata J. Inhibitory effect on aglucosidase by Adhatoda vasica Nees. Food Chem. 2008;108(3):965-72. https://doi.org/10.1016/j.foodchem.2007.12.002.

20. Huang D, Ou B, Prior RL. The chemistry behind antioxidant capacity assays. J Agric Food Chem. 2005;53(6):1841-56. https://doi.org/10.1021/jf030723c.

21. Chinnici F, Bendini A, Gaiani A, Riponi C. Radical scavenging activities of peels and pulps from cv. Golden delicious apples as related to their 
phenolic composition. J Agric Food Chem. 2004;52(15):4684-9. https://doi. org/10.1021/jf049770a.

22. Burčul F, Generalić Mekinić I, Radan M, Rollin P, Blažević I. Isothiocyanates: cholinesterase inhibiting, antioxidant, and anti-inflammatory activity. J Enzyme Inhib Med Chem. 2018;33(1):577-82. https://doi.org/10.1080/147563 66.2018.1442832

23. Pereira-Caro G, Madrona A, Bravo L, Espartero JL, Alcudia F, Cert A, et al. Antioxidant activity evaluation of alkyl hydroxytyrosyl ethers, a new class of hydroxytyrosol derivatives. Food Chem. 2009;115(1):86-91. https://doi.org/1 0.1016/j.foodchem.2008.11.069.

24. Lee JB, Chung WG, Kwahck H, Lee KH. Focal treatment of acne scars with trichloroacetic acid: chemical reconstruction of skin scars method. Dermatol Surg. 2002;28(11):1017-21. https://doi.org/10.1046/j.1524-4725.2002.02095.x.

25. Beydokthi SS, Sendker J, Brandt S, Hensel A. Traditionally used medicinal plants against uncomplicated urinary tract infections: Hexadecyl coumaric acid ester from the rhizomes of Agropyron repens (L.) P. Beauv. with antiadhesive activity against uropathogenic E. coli. Fitoterapia. 2017;117:227. https://doi.org/10.1016/j.fitote.2016.12.010

26. Al Bratty M, Makeen HA, Alhazmi HA, Syame SM, Abdalla AN, Homeida HE, et al. Phytochemical, cytotoxic, and antimicrobial evaluation of the fruits of Miswak plant, Salvadora persica L. J Chem. 2020;2020. https://doi.org/10.11 55/2020/4521951.

27. Desai MN. CNS: bioactive compounds from seed and seed coat of Cynometra Iripa a mangrove species. Universal J Pharm. 2014;6(3):1-5.

\section{Publisher's Note}

Springer Nature remains neutral with regard to jurisdictional claims in published maps and institutional affiliations.

Ready to submit your research? Choose BMC and benefit from:

- fast, convenient online submission

- thorough peer review by experienced researchers in your field

- rapid publication on acceptance

- support for research data, including large and complex data types

- gold Open Access which fosters wider collaboration and increased citations

- maximum visibility for your research: over $100 \mathrm{M}$ website views per year

At $\mathrm{BMC}$, research is always in progress.

Learn more biomedcentral.com/submissions 